62 PENGARUH BERBAGAI KONSENTRASI EKSTRAK BIJI ADAS (Foeniculum vulgare mill.) SEBAGAI

\title{
PENGARUH BERBAGAI KONSENTRASI EKSTRAK BIJI ADAS (Foeniculum vulgare mill.) SEBAGAI DENTURE CLEANSER TERHADAP PERTUMBUHAN CANDIDA ALBICANS PADA PLAT AKRILIK
}

Andhika Ambo ${ }^{*}$ Arlina Nurhapsari ${ }^{* *}$ Erwid Fatchur Rahman ${ }^{* *}$

Keywords:

Fennel Seed, Candida

albicans, Acrilyc Plate,

Denture Cleanser

\section{ABSTRACT}

Introduction: Fennel plant is known as a medicine plant. Fennel plant parts that have the highest content is the seed. Essential oils, flavonoids, and saponins contained in fennel seed have an influence against candida albicans growth. Purpose: This study was conducted to determine the influence of various concentrations of fennel seed extract as a denture cleanser against candida albicans growth on acrilyc plate.

Methods: This research was an experimental laboratoty and study design was an experimental with post test only control group design. Total sample is 30 acrilyc plate measuring $6 \times 1 \mathrm{~cm}$. The sample were divided into 6 groups, 5 groups were soaked in various concentrations of fennel seed extract $(20 \%$, $40 \%, 60 \%, 80 \%, 100 \%)$ and one groups was soaked in control positive polident. Soaking was done for 5 minutes. Candida albicans were incubated for 48 hours at $37^{\circ} \mathrm{C}$. The result of this study were analyzed by one-way ANOVA and LSD (Least Significance Difference).

Results: Based on the one-way ANOVA test was done then obtained significance value of $0,000(p<0,05)$, so it can be concluded that there are significant differences between the two sets groups of at least. Based on the LSD test was done then obtained significance value of $p<0,05$ in all groups which means there are significant differences between each group, except in group fennel seed extract concentration of $100 \%$ with control positive polident obtained 0,924 significance $(p>0,05)$ which means there are no significant differences between two groups.

Conclusion: The researchers' conclusion that there was the influence of various concentration of fennel seed extract as a denture cleanser against candida albicans growth on aclilyc plate. Fennel seed extract concentration of $100 \%$ has the greatest influence as a denture cleanser against candida albicans growth.

\section{PENDAHULUAN}

Masyarakat Indonesia pada usia dewasa dan manula banyak yang mengalami kehilangan gigi baik karena pencabutan atau trauma. Riset Kesehatan Dasar Departemen Kesehatan Republik Indonesia tahun 2007 melaporkan bahwa kehilangan gigi pada kelompok usia 45 - 54 tahun sebesar $1,8 \%$, pada kelompok usia 55 - 64 tahun sebesar $5,9 \%$, dan pada kelompok usia 65 tahun ke atas mencapai 17,6\% ${ }^{1}$. Kehilangan gigi dapat dirawat dengan pemakaian gigi tiruan. Tujuan pemakaian gigi tiruan yaitu untuk mengembalikan fungsi fonetik, fungsi mastikasi, dan fungsi estetik ${ }^{2}$.

Bahan yang digunakan untuk pembuatan gigi tiruan adalah resin akrilik heat cured ${ }^{3}$. Bahan tersebut memiliki sifat berupa porositas. Porositas pada gigi tiruan dapat menjadi tempat yang ideal untuk melekatnya sisa-sisa makanan dan mikroorganisme didalam rongga mulut termasuk candida albicans sehingga dapat berkembangbiak dengan baik. Candida albicans juga akan melekat pada gigi tiruan dan menginfeksi jaringan. Perkembangbiakan candida albicans akan semakin cepat dengan keadaan rongga mulut yang buruk. Hal tersebut

*Program Pendidikan Dokter Gigi Fakultas Kedokteran Gigi Unissula Semarang, ** Staff Pengajar Fakultas Kedokteran Gigi Universitas Islam Sultan Agung Semarang

Korespondensi: amboandhika@yahoo.com 
dapat mengakibatkan denture stomatitis ${ }^{4}$.

Pembersihan gigi tiruan dapat dilakukan secara mekanik dengan menyikat gigi tiruan maupun perendaman gigi tiruan didalam denture cleanser. Perendaman gigi tiruan di dalam denture cleanser lebih efektif karena dapat menjangkau candida albicans di dalam porus. Denture cleanser komersil yang digunakan sekarang ini banyak mengandung bahan kimia ${ }^{5}$. Oleh karena itu, pemerintah menyarankan untuk memanfaatkan tanaman tradisional sebagai alternatif dalam bidang kesehatan $^{6}$.

Indonesia kaya akan tanaman tradisional yang dapat digunakan sebagai obat - obatan, salah satunya adalah tanaman adas (Foeniculum vulgare mill). Penelitian sebelumnya dilakukan Thakur, dkk, (2013) menyatakan ekstrak biji adas memiliki efektifitas sebagai antijamur (Alternaria alternate $)^{7}$. Hal tersebut terjadi karena adanya kandungan minyak atsiri, flavonoid, dan saponin yang berkhasiat sebagai antijamur didalam biji adas ${ }^{8}$.

Penelitian ini dibuat untuk melihat pengaruh berbagai konsentrasi ekstrak biji adas (Foeniculum vulgare mill) sebagai denture cleanser terhadap pertumbuhan candida albicans pada plat akrilik. Biji adas dibuat ekstrak dengan konsentrasi $20 \%, 40 \%$, $60 \%$, $80 \%$, dan $100 \%$ untuk mengetahui konsentrasi ekstrak biji adas yang paling berpengaruh sebagai denture cleanser terhadap pertumbuhan candida albicans pada plat akrilik.

\section{METODE PENELITIAN}

Jenis penelitian ini adalah eksperimental laboratorium dan rancangan penelitian eksperimental dengan rancangan post test only control group desaign. Variabel yang diteliti dalam penelitian ini adalah pertumbuhan candida albicans pada plat akrilik.

Sampel penelitian ini berjumlah 30 plat akrilik yang dibagi dalam 6 kelompok yaitu kelompok perlakuan (ekstrak biji adas konsentrasi $100 \%, 80 \%, 60 \%, 40 \%$, dan $20 \%$ ) dan kelompok kontrol positif (polident). Plat akrilik yang ditumbuhi candida albicans di rendam dalam berbagai konsentrasi ekstrk biji adas $(100 \%, 80 \%, 60 \%, 40 \%$, dan $20 \%)$ dan kontrol positif (polident) selama 5 menit, kemudian dilakukan pembilasan dengan aquades, pengocokan dengan vortex mixer, dan pengenceran seri sampai mencapai suspensi candida albicans 10-3 CFU/ml. Inkubasi candida albicans selama 48 jam dengan suhu $37^{\circ} \mathrm{C}$ kemudian penghitungan dengan colony counter.

\section{HASIL PENELITIAN}

Hasil rata-rata jumlah koloni candida albicans pada masing - masing kelompok terdapat pada tabel 1. Uji statistik diperlukan untuk mengetahui bermakna tidaknya pengaruh berbagai konsentrasi ekstrak biji adas terhadap pertumbuhan candida albicans pada plat akrilik. Langkah pengujian statistik dimulai dengan pengujian normalitas dan homogenitas data untuk menentukan metode analisis yang sesuai. Hasil pengujian data terdapat pada tabel 2.

Tabel 2 menunjukkan hasil uji normalitas data dengan uji Shapiro-Wilk bahwa semua data kelompok perendaman berdistribusi normal dengan nilai signifikansi $>0,05$ yaitu 0,$501 ; 0,616 ; 0,899 ; 0,429 ; 0,783$; dan 0,685 masing-masing untuk kelompok perendaman ekstrak biji adas konsentrasi $20 \%, 40 \%, 60 \%$, $80 \%, 100 \%$, dan kelompok kontrol. 
Tabel 1. Hasil rata-rata perhitungan jumlah koloni candida albicans pada masing - masing kelompok

\begin{tabular}{lccc}
\hline \multicolumn{1}{c}{ Kelompok } & Jumlah sampel & Rata-rata & Standar deviasi \\
\hline Ekstrak Biji Adas 20\% & 5 & 84,8 & 2,59 \\
Ekstrak Biji Adas 40\% & 5 & 62,8 & 3,35 \\
Ekstrak Biji Adas 60\% & 5 & 54,8 & 2,39 \\
Ekstrak Biji Adas 80\% & 5 & 22,4 & 3,78 \\
Ekstrak Biji Adas 100\% & 5 & 12,8 & 3,77 \\
Kontrol dengan Polident & 5 & 12,6 & 3,58 \\
\hline
\end{tabular}

Tabel 2. Hasil Uji Normalitas

\begin{tabular}{lccc}
\hline \multirow{2}{*}{ Kelompok } & \multicolumn{3}{c}{ Shapiro-Wilk } \\
\cline { 2 - 4 } & Statistic & Df & Sig. \\
\hline $20 \%$ & .915 & 5 & .501 \\
$40 \%$ & .933 & 5 & .616 \\
$60 \%$ & .974 & 5 & .899 \\
$80 \%$ & .903 & 5 & .429 \\
$100 \%$ & .956 & 5 & .783 \\
Kontrol & .943 & 5 & .685 \\
\hline
\end{tabular}

Tabel 3. Hasil Uji Homogenitas

\begin{tabular}{cccc}
\hline Levene Statistic & df1 & df2 & Sig. \\
\hline 0,233 & 5 & 24 & 0,944 \\
\hline
\end{tabular}

Berdasarkantabel3, hasil uji homogenitas menggunakan Leuvene test memperoleh nilai signifikansi $>0,05$ yaitu 0,944 , maka semua kelompok berarti homogen.

Berdasarkan tabel 2 dan 3, data dinyatakan berdistribusi normal dan homogen, maka syarat menggunakan uji parametrik Oneway ANOVA terpenuhi. Uji parametrik Oneway ANOVA dilakukan untuk mengetahui perbedaan antar kelompok perendaman. Hasil uji parametrik Oneway ANOVA sebagai berikut:
Tabel 4. Hasil Uji Oneway ANOVA

\begin{tabular}{ccc}
\hline & Df & Sig. \\
\hline $\begin{array}{c}\text { Between } \\
\text { Groups }\end{array}$ & 5 & .000 \\
\hline
\end{tabular}

Berdasarkan tabel 4.4. uji Oneway ANOVA menunjukkan nilai signifikansi < 0,05 yaitu 0,000 . Hal tersebut berarti bahwa ada perbedaan bermakna minimal antara dua pasang kelompok, untuk mengetahui pasangan kelompok mana saja yang berbeda bermakna dilakukan uji Post Hoc LSD. Hasil uji Post Hoc LSD terdapat pada tabel 5. 
Tabel 5. Hasil Uji Post Hoc LSD

\begin{tabular}{|c|c|c|c|c|c|c|}
\hline \multirow{2}{*}{$\begin{array}{l}\text { (I) } \\
\text { kelomp } \\
\text { ok }\end{array}$} & \multirow{2}{*}{$\begin{array}{l}\text { (J) } \\
\text { kelomp } \\
\text { ok }\end{array}$} & \multirow{2}{*}{$\begin{array}{l}\text { Mean } \\
\text { Difference (I- } \\
\text { J) }\end{array}$} & \multirow[b]{2}{*}{ Std. Error } & \multirow[b]{2}{*}{ Sig. } & \multicolumn{2}{|c|}{ 95\% Confidence Interval } \\
\hline & & & & & Lower Bound & Upper Bound \\
\hline \multirow{6}{*}{$20 \%$} & $40 \%$ & $22.00000^{\circ}$ & 2.08006 & .000 & 17.7070 & 26.2930 \\
\hline & $60 \%$ & $30.00000^{\circ}$ & 2.08006 & .000 & 25.7070 & 34.2930 \\
\hline & $80 \%$ & $62.40000^{\circ}$ & 2.08006 & .000 & 58.1070 & 66.6930 \\
\hline & $100 \%$ & $72.00000^{\circ}$ & 2.08006 & .000 & 67.7070 & 76.2930 \\
\hline & Kontrol & $72.20000^{\circ}$ & 2.08006 & .000 & 67.9070 & 76.4930 \\
\hline & $60 \%$ & $8.00000^{\circ}$ & 2.08006 & .001 & 3.7070 & 12.2930 \\
\hline \multirow{3}{*}{$40 \%$} & $80 \%$ & $40.40000^{\circ}$ & 2.08006 & .000 & 36.1070 & 44.6930 \\
\hline & $100 \%$ & $50.00000^{*}$ & 2.08006 & .000 & 45.7070 & 54.2930 \\
\hline & Kontrol & $50.20000^{*}$ & 2.08006 & .000 & 45.9070 & 54.4930 \\
\hline \multirow{3}{*}{$60 \%$} & $80 \%$ & $32.40000^{\circ}$ & 2.08006 & .000 & 28.1070 & 36.6930 \\
\hline & $100 \%$ & $42.00000^{\circ}$ & 2.08006 & .000 & 37.7070 & 46.2930 \\
\hline & Kontrol & $42.20000^{\circ}$ & 2.08006 & .000 & 37.9070 & 46.4930 \\
\hline \multirow[b]{2}{*}{$80 \%$} & $100 \%$ & $9.60000^{\circ}$ & 2.08006 & .000 & 5.3070 & 13.8930 \\
\hline & Kontrol & $9.80000^{\circ}$ & 2.08006 & .000 & 5.5070 & 14.0930 \\
\hline $100 \%$ & Kontrol & 20000 & 2.08006 & 924 & -4.0930 & 4.4930 \\
\hline
\end{tabular}

Tabel 5 menunjukkan dari hasil uji Post Hoc, hampir seluruh kelompok perlakuan memiliki nilai signifikansi $p$ value $<0,05$ yang berarti ada perbedaan bermakna antara seluruh kelompok, kecuali perbandingan antara kelompok ekstrak biji adas konsentrasi $100 \%$ dengan kelompok kontrol dengan polident yang memiliki nilai signifikansi $>0,05$ yang berarti hasilnya memiliki perbedaan yang tidak bermakna.

\section{DISKUSI}

Hasil uji statistik pada penelitian ini diperoleh hasil yang signifikan dari jumlah koloni candida albicans pada masing-masing kelompok perendaman dengan ekstrak biji adas konsentrasi $20 \%, 40 \%, 60 \%, 80 \%$, dan
$100 \%$. Terlihat pada tabel 1 bahwa jumlah rata-rata koloni candida albicans pada kelompok perendaman dengan ekstrak biji adas konsentrasi $20 \%$ memiliki jumlah koloni candida albicans paling banyak dari konsentrasi diatasnya. Ekstrak biji adas konsentrasi 100\% memiliki jumlah koloni candida albicans paling sedikit dari konsentrasi di bawahnya.

Tabel 1 menunjukkan hasil bahwa semakin tinggi konsentrasi ekstrak biji adas maka semakin sedikit jumlah koloni candida albicans. Hal ini disebabkan tanaman adas memiliki kandungan sebagai obat seperti minyak atsiri, flavonoid, dan saponin yang bermanfaat sebagai antijamur ${ }^{9}$. Kandungan tersebut didalam ekstrak biji adas konsentrasi $100 \%$ lebih tinggi dibandingkan dengan konsentrasi yang lebih kecil. 
Minyak atsiri yang diberikan candida albicans tergantung pada kadar fenol didalam minyak atsiri. Kadar fenol yang rendah akan membentuk komplek protein fenol dalam sel candida albicans dan menyebabkan denaturasi protein. Kadar fenol yang tinggi menyebabkan koagulasi protein dan lisisnya membran sel candida albicans ${ }^{10}$. Protein yang mengalami denaturasi dan koagulasi akan kehilangan aktivitas fisiologisnya sehingga tidak dapat berfungsi dengan baik. Perubahan struktur protein pada sel candida albicans akan mengingkatkan permeabilitas sel sehingga pertumbuhan sel candida albicans akan terhambat ${ }^{11}$.

Aktifitas biologi senyawa flavonoid didalam kandungan biji adas dilakukan dengan merusak dinding sel candida albicans. Dinding selnya terdiri dari lipid dan asam amino yang akan bereaksi dengan gugus alkohol pada senyawa flavonoid. Reaksi ini menyebabkan dinding sel rusak dan senyawa flavonoid masuk dalam inti sel jamur. Senyawa tersebut akan berkontak dengan DNA pada inti sel candida albicans sehingga struktur lipid rusak dan inti sel mengalami lisis ${ }^{12}$.

Kandungan saponin yang ada didalam biji adas memiliki aktifitas antijamur bersprektum luas. Kerja saponin merusak membran sitoplasma candida albicans dengan cara meningkatkan premeabilitas membran sel jamur. Saponin merupakan detergen alamiah dan mampu menurunkan tekanan permukaan antara molekul pada suatu permukaan benda. Detergen memiliki gugus hidrokarbon yang larut lemak dan berada pada membran sel. Hal tersebut menyebabkan sel - sel pada membran sitoplasma menjadi lisis 12 .

Terlihat pada tabel 4 dan 5 bahwa terdapat perbedaan antar berbagai ekstrak biji adas sebagai denture cleanser pada pertumbuhan candida albicans pada plat akrilik dan menunjukkan perbedaan yang bermakna antara berbagai konsentrasi ekstrak biji adas. Hal ini terjadi karena kandungan minyak atsiri, flavonoid, dan saponin didalam berbagai konsentrasi ekstrak biji adas berbeda. Ekstrak biji adas konsentrasi $100 \%$ yaitu 12,8 menghasilkan jumlah yang tidak berbeda jauh dengan kontrol positif berupa polident yaitu 12,6. Hal tersebut dapat dilihat dari kandungan polident yang berupa bahanbahan kimia diantaranya citric acid dan sodium bicarbonate ${ }^{13}$.

\section{KESIMPULAN}

1. Terdapat perbedaan signifikan dari pengaruh berbagai konsentrasi ekstrak biji adas sebagai denture cleanser terhadap pertumbuhan candida albicans pada plat akrilik

2. Ekstrak biji adas dari konsentrasi $20 \%, 40 \%, 60 \%, 80 \%$, hingga $100 \%$ menunjukkan penurunan jumlah koloni candida albicans, hal ini menunjukkan semakin tinggi konsentrasi ekstrak biji adas maka pertumbuhan candida albicans semakin dapat dihambat

3. Ekstrak biji adas konsentrasi $100 \%$ merupakan konsentrasi yang paling menghambat pertumbuhan candida albicans, tetapi tidak berbeda bermakna dengan kontrol positif polident

\section{DAFTAR PUSTAKA}

1. Riset Kesehatan Dasar. Laporan Nasional. Jakarta. (2007). terbitan.litbang.depkes.go.id

2. Tarigan S. Pasien Prostodonsia Lanjut Usia: Beberapa Pertumbangan dalam Perawatan. Universitas Sumatra Utara. (2005). http:// www.researchgate.net/publication/42319927 Pasien_Prostodonsia_Lanjut_Usia_Beberapa_Pertimbangan_Dalam_Keperawatan

3. Hussain S. Textbook of Dental Materiasl. New Delhi: Jaypee. Hal 405. (2004).

4. Zarb GA, Hobkrik J, Eckert S, Jacob R. Phrostodontic Treatment for Edentulous Patients: Complete Dentures and Implant-Supported Prostheses. United State: Elsevier. Hal 45-47. (2013).

5. Fraunhofer JAV. Dental Material at a Glance. Oxford: Wiley. Hal 53. (2013).

6. Departemen Kesehatan Republik Indonesia. Kebijakan Obat Tradisional. Jakarta. (2007). binfar. depkes.go.id 
7. Thakur N, Shareen N, Shama B, and Jogota K. Studies on In Vitro Antifungal Activity of Foeniculum vulgare mill. Against Spoilage Fungi. Global Journal of Bio-science and Biotechnology. Vol. 2 (3). H. 427430. (2013).

8. Utami P and Puspaningtyas DE. The Miracles of Herbs. Jakarta: Agromedia. Hal 23-24. (2013).

9. Sastrawan IN, Sangi M, and Kamu V. Skrining Fitokimia dan Uji Antioksidan Ekstrak Biji Adas (Foeniculum vulgare) Menggunakan Metode DPPH. Jurnal IImiah Sains. Vol. 13 No. 2. Hal 110-115. (2013).

10. Parwata IM dan Dewi PF. Isolasi dan Uji Aktivitas Antibakteri Minyak Atsiri dari Rimpang Lengkuas (Alpinia galanga L). Jurnal Kimia 2 (2). Hal 100-104. (2008).

11. Agustin D. Perbedaan Khasiat Antibakteri Bahan Irigasi antara Hidrogen Peroksida 3\% dan Infusum Daun Sirih 20\% terhadap Bakteri Mix. Dent J. Vol. 38, No. 1, Hal 45-47. (2005).
12. Winarsih S, Rosita R, and Nurkhayya I. Hambatan Ekstrak Etanol Gel Lidah Buaya (Aloe vera) Terhadap Pertumbuhan Jamur Candida albicans Isolat Vagina 218 SV Secara in Vitro. Jurnal Penelitian. Hal 1-14. (2011).

13. Ural Ural C, Sanal FA, Cengiz S. Effect of Different Denture Cleanser on Surface Roughness of Denture Base Materials. Clinical Dentistry and Research. 35(2): 14-20. (2011). 